\title{
Phosphorus fertilization of 'Fuyutoyo' cabbages in phosphorus-rich Eutrustox soil
}

\author{
Arthur Bernardes Cecílio Filho ${ }^{1 *}$, Gilson Silverio da Silva ${ }^{1}$, and Juan Waldir Mendoza Cortez ${ }^{1}$
}

Crop fertilization with $\mathrm{P}$ is a practice that constantly needs to be improved because of its high cost, natural reserve constraints, and environmental impact caused by the excessive use of nutrients. Phosphorus rates $(0,120,240,360,480,600$, and 720 $\mathrm{kg} \mathrm{P}_{2} \mathrm{O}_{5} \mathrm{ha}^{-1}$ ) in the cultivation of 'Fuyutoyo' cabbage (Brassica oleracea L. var. capitata) in a P-rich Eutrustox soil (93

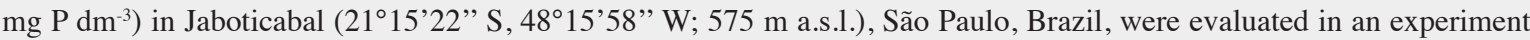
with a randomized complete block design with three replicates. Phosphorus rates influenced plant characteristics and soil $\mathrm{P}$ content. Maximum leaf and soil $\mathrm{P}$ content was obtained with $720 \mathrm{~kg} \mathrm{P}_{2} \mathrm{O}_{5}$ ha $^{-1}$, but maximum values of leaf area, leaf dry mass, cabbage head mass, and productivity were obtained with 420,310 , 430, and $437.5 \mathrm{~kg} \mathrm{ha}^{-1} \mathrm{P}_{2} \mathrm{O}_{5}$, respectively. Results indicate that even crops grown in a P-rich soil benefit from applying $\mathrm{P}$ fertilizer, which has a positive effect on the growth and productivity of the 'Fuyutoyo' cabbage.

Key words: Brassica oleracea var. capitata, excess phosphorus, plant nutrition.

\section{INTRODUCTION}

Cabbage (Brassica oleracea $\mathrm{L}$. var. capitata) is the main commercial species of the Brassicaceae family and is among the most economically important vegetable crops in Brazil. It is also one of the crops for which information on soil fertilization is still inadequate.

Phosphorus is a strategic nutrient for cabbage plant management even though only small quantities are absorbed (Khan et al., 2002). The levels of this nutrient in diagnostic leaves for cabbage optimal growth are between 4 and $7 \mathrm{~g} \mathrm{~kg}^{-1}$ (Trani and van Raij, 1997) and between 3 and $5 \mathrm{~g} \mathrm{~kg}^{-1}$ for herbaceous plants in general (Hawkesford et al., 2012). Phosphorus is an important nutrient in crop productivity and is used in several metabolic processes such as photosynthesis, respiration, cell division, biosynthesis, and ionic absorption. It is also a component of structural phospholipids, nucleic acids, coenzymes, and phosphoproteins (Sanchez, 2006; Fageria, 2009; Hawkesford et al., 2012).

The response of crop species to $\mathrm{P}$ depends on the species and on $\mathrm{P}$ soil availability (Wang and $\mathrm{Li}, 2004$ ). Crop species growing in P-deficient soils generally respond well to $\mathrm{P}$ fertilization, but plants do not usually respond when $\mathrm{P}$ levels in the soil are greater than $70 \mathrm{mg}$

${ }^{1}$ Universidade Estadual Paulista, Faculdade de Ciências Agrárias e Veterinárias, Via de acesso Prof. Paulo Donato Castellane, s/n, 14.884900, Jaboticabal, São Paulo, Brasil.

*Corresponding author (rutra@fcav.unesp.br).

Received: 27 November 2012.

Accepted: 19 June 2013.

doi:10.4067/S0718-58392013000300012 $\mathrm{dm}^{-3}$ (Castellane et al., 1988). However, Deenik et al. (2006) reported that cabbage plants subjected to rates of 0 to $198 \mathrm{~kg} \mathrm{P} \mathrm{ha}^{-1}$ in soil containing $351 \mathrm{mg} \mathrm{P} \mathrm{dm}^{-3}$ responded positively to rates of up to $50 \mathrm{~kg} \mathrm{ha}^{-1}$ and that responses diminished above that rate. These results can be due to the low efficiency of some genotypes in absorbing and using P (Sanchez, 2006; Fageria, 2009). The positive response is one of the reasons why farmers use high $\mathrm{P}$ fertilizer rates.

Plant $\mathrm{P}$ availability is also hampered in highly weathered soils, such as tropical soils, that are usually acidic with a high potential of iron and aluminum oxides to absorb P (Valladares et al., 2003; Raij, 2004; Hopkins and Ellsworth, 2005). This strong interaction with the soil is why $\mathrm{P}$ is applied at the highest rates to crops in tropical areas (Rao et al., 1999). In addition, vegetable crops usually have short cycles so that their demand for nutrients is concentrated over a short period of time (Sanchez, 2006).

Cabbage plant response to $\mathrm{P}$ in highly weathered tropical soils warrants further study because the excessive use of $\mathrm{P}$ has a high potential for polluting and causing the eutrophication of bodies of water (Sharpley et al., 2003; Fageria, 2009). Decreases in biomass have been reported to be associated with excessive $\mathrm{P}$ levels and reduced micronutrient levels (Hopkins and Ellsworth, 2003; Sanchez, 2006; Fageria, 2009). High P levels are usually observed in soils frequently cultivated with vegetable crops (Deenik et al., 2006).

The objective of this research study was to evaluate the effects of the P rate on 'Fuyutoyo' cabbages grown in P-rich typical clay Oxisol. 


\section{MATERIALS AND METHODS}

The experiment was conducted at the Experimental Farm of the São Paulo State University (UNESP) in Jaboticabal (2115'22" S, 48 15'59" W; 575 m a.s.l.), São Paulo State, Brazil. The soil of the experimental area is typical clay Oxisol (Soil Survey Staff, 1975) with 560, 250, and $190 \mathrm{~g} \mathrm{~kg}^{-1}$ clay, silt, and sand, respectively. The initial soil chemical characteristics in the 0 to $20 \mathrm{~cm}$ layer were 4.0 $\mathrm{pH}_{(\mathrm{CaCl} 2)} ; 14.0 \mathrm{~g} \mathrm{dm}^{-3}$ organic matter; $93.0 \mathrm{mg} \mathrm{dm}^{-3} \mathrm{P}_{(\mathrm{resin})}$; $0.33,1.5,0.6,0.1,3.8$, and $6.23 \mathrm{cmol}_{\mathrm{c}} \mathrm{dm}^{-3}$ of $\mathrm{K}, \mathrm{Ca}, \mathrm{Mg}$, $\mathrm{Al}, \mathrm{H}+\mathrm{Al}$, and cationic exchange capacity, respectively; $0.3,3.9,15.0,18.9,2.1$, and $9.0 \mathrm{mg} \mathrm{dm}^{-3}$ of $\mathrm{B}, \mathrm{Cu}, \mathrm{Fe}$, $\mathrm{Mn}, \mathrm{Zn}$, and $\mathrm{S}_{-} \mathrm{SO}_{4}{ }^{2-}$, respectively; and a base saturation of $39 \%$. According to Raij et al. (1997), soil P level was high. Seven P rates were evaluated: 0, 120, 240, 360, 480,600 , and $720 \mathrm{~kg} \mathrm{P}_{2} \mathrm{O}_{5} \mathrm{ha}^{-1}$. These rates followed the recommendation of $200 \mathrm{~kg} \mathrm{ha}^{-1}$ by Trani et al. (1997) for cabbage when soil P level is greater than $60 \mathrm{mg} \mathrm{P} \mathrm{dm}^{-3}$.

This field experiment was conducted with a randomized complete block design of seven treatments and three replicates. Each plot was $2625 \times 1.10 \mathrm{~m}$ in size with two rows of seven plants for a density of 35340 plants ha $^{-1}$. The first and last plants in each row were not included in the analyses to avoid edge effects.

Hybrid 'Fuyutoyo' cabbage seedlings were raised in 200-cell polypropylene trays. Following the recommendation by Trani et al. (1997), soil from the experimental area was limed to raise the soil base saturation to $80 \%$. Agricultural lime (total neutralizing power of 126\%) was distributed over the entire area and then incorporated with a harrow. The soil was plowed, harrowed, and finally formed into seed beds with a rotavator. No organic fertilizers were added. Before transplanting the seedlings, $60 \mathrm{~kg} \mathrm{~N}^{-1}$ (ammonium sulfate), $120 \mathrm{~kg} \mathrm{~K}_{2} \mathrm{O} \mathrm{ha}^{-1}$ (potassium chloride), and $4 \mathrm{~kg}$ pulverized $\mathrm{B} \mathrm{ha}^{-1}$ (borax) were applied to each seed bed. The applied $\mathrm{P}$ rates (triple superphosphate) corresponded to those of the treatments. These applications were incorporated into the soil to a depth between 10 and 15 $\mathrm{cm}$.

Row spacing in the plots was $0.60 \mathrm{~m}$, and seedling planting distance was $0.35 \mathrm{~m}$. Seedlings were transplanted on 17 February 2009 and irrigated soon afterwards with a sprinkler irrigation system. Nitrogenous and $\mathrm{K}$ fertilizers were equally applied to the plants as side dressings at 15 , 30 , and $45 \mathrm{~d}$ after transplanting (DAT). Nitrogen fertilizer (ammonium sulfate) was applied at a total rate of $180 \mathrm{~kg}$ $\mathrm{ha}^{-1}$ and $\mathrm{K}$ fertilizer (potassium chloride) at a total rate of $120 \mathrm{~kg} \mathrm{ha}^{-1}$. Weeds were hoed when necessary and insecticides were sprayed to control Plutella xylostella, Diabrotica speciosa, Brevicoryne brassicae, and Bemisia argentifolii. Fungicides were required to control Alternaria spp. Cabbages were harvested on 6 May 2009, 79 DAT and $120 \mathrm{~d}$ after seeding the polypropylene trays. All treatments were harvested on the same day. Cabbages were harvested when $80 \%$ of the heads in one treatment were considered suitable for commercial purposes.

The following characteristics were measured: 1) Leaf $\mathrm{P}$ content $\left(\mathrm{g} \mathrm{kg}^{-1}\right)$ : One leaf from 10 plants per plot was collected as recommended by Trani and Raij (1997). Leaves were washed in tap water and then with deionized water, placed in paper bags, and dried in a forcedventilation oven at $65^{\circ} \mathrm{C}$ to constant weight. Leaves were then ground and extracted to determine P content. 2) Leaf area $\left(\mathrm{LA} ; \mathrm{dm}^{2}\right.$ plant $\left.^{-1}\right)$ : At harvest, leaf areas of the head external leaves (photosynthetically active leaves) of four plants per plot were measured with an electronic area meter (LI-3100C, LI-COR, Lincoln, Nebraska, USA). 3) Dry mass of head external leaves (LDM; g plant ${ }^{-1}$ ): After harvest, leaves of four plants per plot were washed and dried in a forced-ventilation oven at $65{ }^{\circ} \mathrm{C}$ to constant weight. 4) Plant head fresh mass (HFM; g plant ${ }^{-1}$ ): After harvest, heads of all 10 plants per plot were weighed. 5) Productivity (PROD; $\mathrm{kg} \mathrm{m}^{2}$ ): The total of all 10 cabbage head masses per plot. 6) Phosphorus soil content (mg $\left.\mathrm{dm}^{-3}\right)$ : Ten soil samples were collected at the end of the experiment from each plot and bulked to form a composite sample to determine soil available $\mathrm{P}$ content in accordance with Raij et al. (2001). 7) Phosphorus accumulation in leaves, stems, and heads, and total $\mathrm{P}\left(\mathrm{mg} \mathrm{plant}^{-1}\right)$ : At harvest, leaves, stems, and heads from four plants from each plot were separated and washed in tap water and then with deionized water. These materials were dried in a forced-ventilation oven at $65^{\circ} \mathrm{C}$ to constant weight and then ground. The $\mathrm{P}$ levels were determined. Accumulated $\mathrm{P}$ was calculated by multiplying $\mathrm{P}$ levels in the leaves, stems, and heads by the corresponding dry masses of each part. Total $\mathrm{P}$ accumulated in the plants corresponded to the sum of the quantities of $\mathrm{P}$ accumulated in the leaves, stems, and heads. Phosphorus exportation (\%) corresponded to the quantity of $P$ accumulated in the cabbage head.

Data were analyzed by ANOVA F-tests and polynomial regression. The equation with the highest level of significance was chosen to represent an association.

\section{RESULTS AND DISCUSSION}

The LAs and LDMs of 'Fuyutoyo' cabbages were significantly influenced by the $\mathrm{P}$ rate (Table 1) and quadratic equations were significantly adjusted to the observed means (Figure 1). A rate of $420 \mathrm{~kg} \mathrm{P}_{2} \mathrm{O}_{5} \mathrm{ha}^{-1}$ produced the highest LA $\left(75.05 \mathrm{dm}^{2}\right.$ plant $\left.^{-1}\right)$, which represented an increase of $39.5 \%$ as compared with the control $\left(0 \mathrm{~kg} \mathrm{P}_{2} \mathrm{O}_{5} \mathrm{ha}^{-1} ; 53.8 \mathrm{dm}^{2}\right.$ plant $\left.^{-1}\right)$ (Figure 1). Leaf dry mass increased to $65.25 \mathrm{~g} \mathrm{plant}^{-1}$ at $310 \mathrm{~kg} \mathrm{P}_{2} \mathrm{O}_{5}$ $\mathrm{ha}^{-1}$. Above this rate, LDM decreased with increasing $\mathrm{P}_{2} \mathrm{O}_{5}$ rates; at $720 \mathrm{~kg} \mathrm{P}_{2} \mathrm{O}_{5}$ ha $^{-1}$, LDMs were $69 \%$ and $49 \%$ lower than those of the control treatment and the highest LDM, respectively (Figure 1).

The effects on LA and LDM are due to the functions $\mathrm{P}$ has in plants, that is, photosynthesis, cell division, ion 
Table 1. Leaf area (LA), leaf dry mass (LDM), leaf P content (LP), head fresh mass (HFM), and productivity (PROD) of 'Fuyutuyo' cabbage plants affected by $P$ fertilizer rates.

\begin{tabular}{lccccc}
\hline $\mathrm{P}_{2} \mathrm{O}_{5}$ & LA & LDM & LP & HFM & PROD \\
\hline $\mathrm{kg} \mathrm{ha}^{-1}$ & $\mathrm{dm}^{2}$ plant $^{-1}$ & g plant $^{-1}$ & $\mathrm{~g} \mathrm{~kg}^{-1}$ & $\mathrm{~g} \mathrm{plant}^{-1}$ & $\mathrm{~kg} \mathrm{~m}^{-2}$ \\
0 & 49.43 & 42.49 & 3.83 & 1630.23 & 7.76 \\
120 & 68.31 & 59.03 & 4.13 & 1655.87 & 7.88 \\
240 & 77.97 & 72.97 & 3.63 & 1948.02 & 9.27 \\
360 & 70.41 & 68.06 & 3.40 & 1760.50 & 8.38 \\
480 & 73.28 & 49.88 & 3.70 & 1968.55 & 9.37 \\
600 & 68.08 & 51.89 & 4.03 & 1935.35 & 9.21 \\
720 & 69.02 & 39.18 & 4.33 & 1710.92 & 8.15 \\
Treatments & $2.57^{\mathrm{NS}}$ & $5.60^{* *}$ & $3.92^{*}$ & $2.98^{\mathrm{NS}}$ & $2.98^{\mathrm{NS}}$ \\
$1^{\text {st }}$ degree regression & $3.31^{\mathrm{NS}}$ & $2.82^{\mathrm{NS}}$ & $2.54^{\mathrm{NS}}$ & $3.41^{\mathrm{NS}}$ & $3.39^{\mathrm{NS}}$ \\
$2^{\text {nd }}$ degree regression & $7.86^{*}$ & $22.60^{* *}$ & $12.40^{* *}$ & $7.29 *$ & $7.22^{*}$ \\
$3^{\text {rd }}$ degree regression & $3.23^{\mathrm{NS}}$ & $4.28^{\mathrm{NS}}$ & $1.80^{\mathrm{NS}}$ & $1.11^{\mathrm{NS}}$ & $1.12^{\mathrm{NS}}$ \\
$\mathrm{CV}^{*} \%$ & 4.17 & 16.83 & 7.26 & 8.13 & 8.12 \\
\hline
\end{tabular}

**Significant at $\mathrm{P} \leq 0.01$; *significant at $\mathrm{P} \leq 0.05$; ${ }^{\mathrm{NS}}$ non significant.

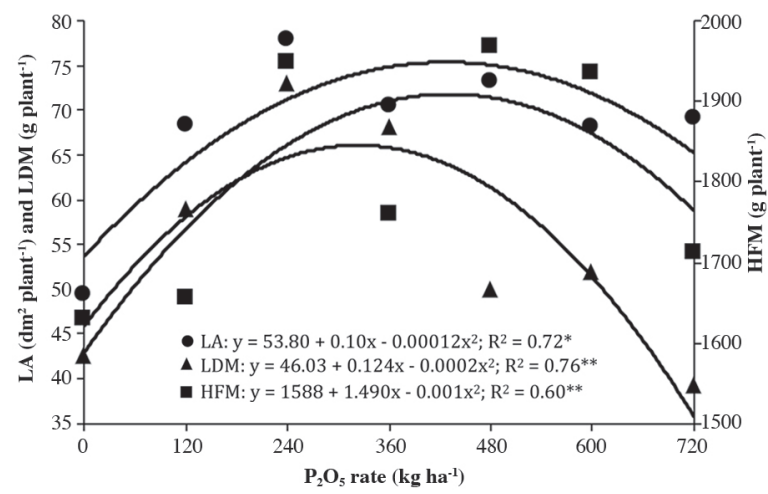

Figure 1. Leaf area (LA), leaf dry mass (LDM), and head fresh mass (HFM) of 'Fuyutuyo' cabbage plants affected by $P$ fertilizer rates.

absorption and transport, and biosynthetic processes. Phosphorus also plays a role in root growth, especially of secondary roots, which makes water and nutrient absorption easier and more efficient with a direct effect on the growth of aboveground tissues (Sanchez, 2006; Fageria, 2009; Hawkesford et al., 2012). On the other hand, 'Fuyutoyo' cabbages did not continue to respond to increased $P$ rates perhaps because cabbage plants have an internal regulation system by which $\mathrm{P}$ transporters block $\mathrm{P}$ absorption when the amount of soil $\mathrm{P}$ is higher than what is required for optimal growth (Hawkesford et al., 2012).

Leaf $\mathrm{P}$ content was significantly influenced by the $\mathrm{P}$ rate (Table 1) and the quadratic equations were adjusted. A rate of $720 \mathrm{~kg} \mathrm{P}_{2} \mathrm{O}_{5}$ ha $^{-1}$ produced the highest leaf $\mathrm{P}$ content (4.3 $\left.\mathrm{g} \mathrm{plant}^{-1}\right)$ (Figure 2). Dechassa et al. (2003) evaluated the effects of six P rates $(0,12,27,73,124$, and $234 \mathrm{mg} \mathrm{kg}^{-1}$ ) applied to soil with $16 \mathrm{mg} \mathrm{P} \mathrm{kg}^{-1}$ (extractor calcium-acetate-lactate) and also found that $\mathrm{P}$ content of aboveground tissues of cabbage plants increased significantly with increased soil $\mathrm{P}$.

In accordance with the polynomial regression, leaf $\mathrm{P}$ levels resulting from rates lower than 16 and higher than $484 \mathrm{~kg} \mathrm{P}_{2} \mathrm{O}_{5} \mathrm{ha}^{-1}$ are within the range considered to be adequate (between 4 and $7 \mathrm{~g} \mathrm{~kg}^{-1}$ ) by Trani and Raij (1997). When rates were between 17 and $483 \mathrm{~kg} \mathrm{P}_{2} \mathrm{O}_{5}$

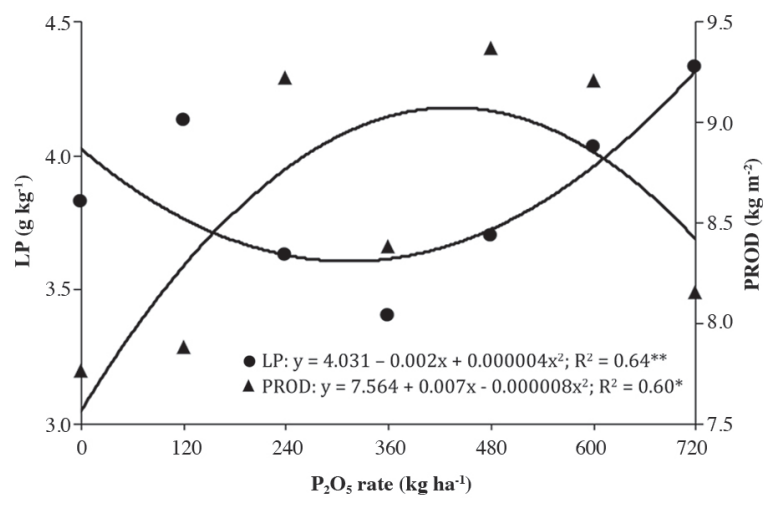

Figure 2. Phosphorus content of the diagnostic leaf (LP) and productivity (PROD) of 'Fuyutuyo' cabbage plants affected by $P$ fertilizer rates.

$\mathrm{ha}^{-1}, \mathrm{P}$ contents were inadequate, although no symptoms of $\mathrm{P}$ deficiency were observed. Adequate P levels have been estimated as 3.0 (Malavolta et al., 1997) and $4.2 \mathrm{mg}$ $\mathrm{kg}^{-1}$ (Martinez et al., 1999) when the nutritional status is evaluated in the intermediate leaf (recently matured or recently developed) (Trani and Raij, 1997). The polynomial adjustment observed for leaf $\mathrm{P}$ levels in the diagnostic leaf is the opposite of that observed in the LA and LDM adjustments. This reduction in leaf $\mathrm{P}$ content coincides with the range of the highest growth values, which is probably due to a dilution effect. An insufficient amount of $\mathrm{P}$ in the plants was unlikely.

Plant head fresh mass (HFM) and PROD were significantly influenced by the $\mathrm{P}$ rate (Table 1) and showed polynomial quadratic adjustments (Figures 1 and 2). A rate of $430 \mathrm{~kg} \mathrm{P}_{2} \mathrm{O}_{5}$ ha $^{-1}$ produced the highest $\mathrm{HFM}$ (1910 $\mathrm{g} \mathrm{plant}^{-1}$ ) (Figure 1). This rate is $115 \%$ higher than that recommended by Trani et al. (1997), that is, $200 \mathrm{~kg}$ $\mathrm{P}_{2} \mathrm{O}_{5}$ ha $^{-1}$ for P-rich soils with $\mathrm{P}$ content greater than 60 $\mathrm{mg} \mathrm{dm}{ }^{-3}$. However, the rate needed to produce cabbage heads weighing $95 \%$ of the maximum mass was $197 \mathrm{~kg}$ $\mathrm{P}_{2} \mathrm{O}_{5}$ ha $^{-1}$; this confirms the rate recommended by Trani et al. (1997). A rate of $437.5 \mathrm{~kg} \mathrm{P}_{2} \mathrm{O}_{5}$ ha $^{-1}$ yielded maximum PROD $\left(9.10 \mathrm{~kg} \mathrm{~m}^{-2}\right)$. Rates above this level, up to $720 \mathrm{~kg}$ $\mathrm{ha}^{-1}$, led to decreases in productivity $\left(8.40 \mathrm{~kg} \mathrm{~m}^{-2}\right)$ of up to $7.6 \%$ (Figure 2). Growth and productivity data indicated that 'Fuyutoyo' cabbages responded well to $\mathrm{P}$ fertilizers even in a P-rich Eutrustox soil (93 $\mathrm{mg} \mathrm{P} \mathrm{dm}^{-3}$ ) (Raij et al., 1997). Deenik et al. (2006) also reported a good response in cabbages in soil with $351 \mathrm{mg} \mathrm{P} \mathrm{dm}^{-3}$.

Phosphorus accumulation in the stem, different from accumulation in leaves, heads, and whole plants, was significantly influenced by the Prate (Table 2). Phosphorus accumulation in the stem was verified and adjusted to a linear equation with proportional increases as the $\mathrm{P}$ rate increased (Figure 3). The regression did not significantly adjust to $\mathrm{P}$ accumulation in leaves, heads, and whole plants. Accumulated amounts for each $\mathrm{P}$ rate are shown in Table 2. Phosphorus was accumulated in small amounts in the whole plant. The participation of the different organs 
Table 2. Phosphorus stem accumulation (PSA), $P$ leaf accumulation (PLA), $\mathbf{P}$ head accumulation - exportation (PEX), $\mathbf{P}$ total accumulation (PTA) of 'Fuyutuyo' cabbage plants and soil $P$ content (PS) affected by $P$ fertilizer rates.

\begin{tabular}{|c|c|c|c|c|c|}
\hline$\underline{\mathrm{P}_{2} \mathrm{O}_{5}}$ & PSA & PLA & PEX & PTA & PS \\
\hline $\mathrm{kg} \mathrm{ha}^{-1}$ & \multicolumn{4}{|c|}{$\longrightarrow$ mg plant $^{-1}$} & $\mathrm{mg} \mathrm{dm}^{-3}$ \\
\hline 0 & 14.35 & 143.28 & 310.99 & 468.63 & 144.67 \\
\hline 120 & 21.18 & 148.03 & 373.71 & 542.93 & 156.00 \\
\hline 240 & 27.64 & 154.75 & 375.21 & 557.60 & 168.03 \\
\hline 360 & 46.10 & 182.64 & 450.49 & 682.56 & 165.33 \\
\hline 480 & 36.08 & 169.41 & 389.25 & 594.75 & 211.00 \\
\hline 600 & 37.49 & 183.23 & 338.98 & 559.69 & 222.00 \\
\hline 720 & 39.90 & 177.25 & 370.32 & 587.48 & 232.00 \\
\hline Treatments & $3.90 *$ & $0.75^{\mathrm{NS}}$ & $0.63^{\mathrm{NS}}$ & $0.85^{\mathrm{NS}}$ & $5.26^{* *}$ \\
\hline $1^{\text {st }}$ degree regression & $15.32 * *$ & $3.35^{\mathrm{NS}}$ & $0.18^{\mathrm{NS}}$ & $1.34^{\mathrm{NS}}$ & $29.09 * *$ \\
\hline $2^{\text {nd }}$ degree regression & $4.01^{\mathrm{NS}}$ & $0.32^{\mathrm{NS}}$ & $1.89^{\mathrm{NS}}$ & $2.02^{\mathrm{NS}}$ & $0.37^{\mathrm{NS}}$ \\
\hline $3^{\text {rd }}$ degree regression & $0.00^{\mathrm{NS}}$ & $0.11^{\mathrm{NS}}$ & $0.36^{\mathrm{NS}}$ & $0.15^{\mathrm{NS}}$ & $0.33^{\mathrm{NS}}$ \\
\hline $\mathrm{CV}, \%$ & 30.93 & 20.20 & 25.37 & 21.15 & 14.29 \\
\hline
\end{tabular}

**Significant at $\mathrm{P} \leq 0.01$; *significant at $\mathrm{P} \leq 0.05$; ${ }^{\mathrm{NS}}$ non significant.

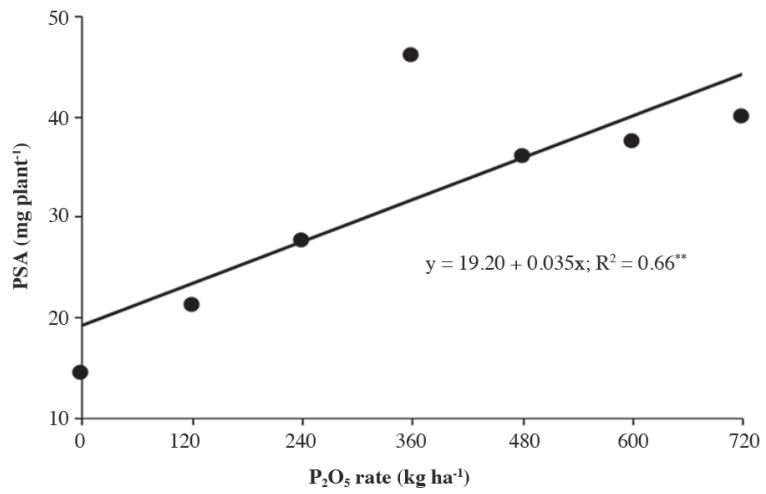

Figure 3. Phosphorus stem accumulation (PSA) of 'Fuyutuyo' cabbage plants affected by $P$ fertilizer rates.

in total $\mathrm{P}$ accumulation obeyed the following order: heads (exportation) contributed 65\% (372.7 $\left.\mathrm{mg} \mathrm{plant}^{-1}\right)$, leaves approximately $29 \%\left(165.5 \mathrm{mg} \mathrm{plant}^{-1}\right)$, and stems $6 \%$ (31.8 mg plant $\left.^{-1}\right)$.

Soil $\mathrm{P}$ content after harvesting was significantly influenced by the $\mathrm{P}$ rate (Table 2). Soil $\mathrm{P}$ content was found to be adjusted to a linear equation with proportional increases as the $\mathrm{P}_{2} \mathrm{O}_{5}$ rates increased. Soil $\mathrm{P}$ content varied between 139 and $232 \mathrm{mg} \mathrm{dm}^{-3}$ (Figure 4). Deenik et al. (2006) also found that adding P fertilizers to the soil led to

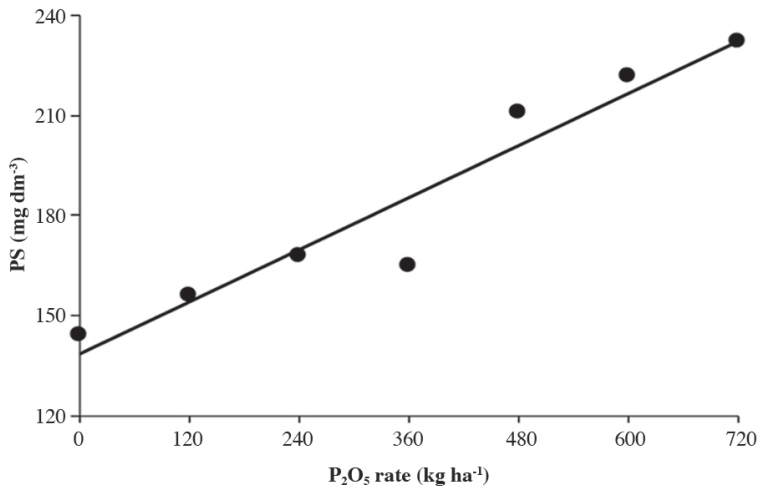

Figure 4. Phosphorus soil content (PS) after cabbage plant harvest affected by $\mathbf{P}$ fertilizer rates. soil P levels above the basal level of $351 \mathrm{mg} \mathrm{dm}^{-3}$ (where no $\mathrm{P}$ was applied) to $530 \mathrm{mg} \mathrm{dm}^{-3}$ (where the highest $\mathrm{P}_{2} \mathrm{O}_{5}$ rates had been applied). According to these authors, the use of completely formulated fertilizers is likely to increase soil $\mathrm{P}$ levels over time in several areas where horticultural production is intense.

\section{CONCLUSIONS}

Results indicate that applying P fertilizers increases the productivity of 'Fuyutoyo' cabbages even in P-rich soils.

\section{ACKNOWLEDGEMENTS}

We thank the Graduate Program in Agronomy (Plant Production) of the Universidade Estadual Paulista Júlio de Mesquita Filho (UNESP), Jaboticabal Campus, Coordenação de Aperfeiçoamento de Pessoal de Nivel Superior (CAPES) for providing a doctoral scholarship and our colleagues Ivan Soares de Araujo, Sergio Mendonça Mendes, and Filipe Norberto Ayres de Freitas.

\section{LITERATURE CITED}

Castellane, P.D., M.E. Ferreira, e A.H. Maeda. 1988. Diagnose da fertilidade dos solos cultivados com olerícolas em Atibaia (SP). Horticultura Brasileira 6:50.

Dechassa, N., M.K. Schenk, N. Claassen, and B. Steingrobe. 2003. Phosphorus efficiency of cabbage (Brassica oleraceae L. var. capitata), carrot (Daucus carota L.), and potato (Solanum tuberosum L.) Plant and Soil 250:215-224.

Deenik, J., R. Hamasaki, R. Shimabuku, S. Nakamoto, and R. Uchida. 2006. Phosphorus fertilizer management for head cabbage. Soil and Crop Management 16:1-6.

Fageria, N.K. 2009. The use of nutrients in crop plants. 430 p. Taylor \& Francis Group, Boca Raton, Florida, USA.

Hawkesford, M., W. Horst, T. Kichey, H. Lambers, J. Schjoerring, I. Skrumsager Moller, and P. White. 2012. Function of macronutrients. p. 135-178. In Marschner, P. (ed.) Marschner's mineral nutrition. $3^{\text {rd }}$ ed. Elsevier Ltd., Oxford, UK.

Hopkins, B.G., and J.W. Ellsworth. 2003. Phosphorus nutrition in potato production. p. 75-86. In Robertson, L.D., et al. (eds.) Proceedings of the Winter Commodity Schools -2003 . University of Idaho-Cooperative Extension System, Moscow, Idaho, USA.

Hopkins, B., and J.W. Ellsworth. 2005. Phosphorus availability with alkaline/calcareous soil. p. 88-93. In $6^{\text {th }}$ Western Nutrient Management Conference, Salt Lake City, Utah. 3-4 March. Potash and Phosphate Institute, Norcross, Georgia, USA.

Khan, R., S. Ahmed, S. Khan, F. Ahmed, M. Zaman, and B.A. Khan. 2002. Effect of different levels of nitrogen, phosphorus and potassium on the growth and yield of cabbage. Asian Journal of Plant Sciences 1:548-549.

Malavolta, E., G.C. Vitti, e S.A. Oliveira. 1997. Avaliação do estado nutricional das plantas: princípios e aplicações. 319 p. $2^{\text {a }}$ ed. POTAFOS, Piracicaba, São Paulo, Brasil.

Martinez, H.E.P., J.G. Carvalho, e R.B. Souza. 1999. Diagnose foliar. p. 143-168. In Ribeiro, A.C., et al. (eds.) Recomendações para o uso de corretivos e fertilizantes em Minas Gerais - $5^{\text {a }}$ aproximação. Comissão de Fertilidade do Solo do Estado de Minas Gerais, Viçosa, Minas Gerais, Brasil.

Raij, B. van. 2004. Fósforo no solo e interação com outros elementos. p. 107-108. In Yamada, T., e S.R.S. Abdalla (eds.) Fósforo na agricultura brasileira. POTAFOS, Piracicaba, São Paulo, Brasil. 
Raij, B. van, J.C. Andrade, H. Cantarella, e J.A. Quaggio. 2001. Análise química para avaliação da fertilidade de solos tropicais 285 p. Instituto Agronômico \& Fundação IAC, Campinas, São Paulo, Brasil.

Raij, B. van, A.J. Quaggio, H. Cantarella, e C.A. Abreu. 1997. Interpretação de resultados de análise de solos. p. 8-13. In Raij, B. van, et al. (eds.) Recomendações de adubação e calagem para o Estado de São Paulo. Boletim Técnico 100. $2^{\text {a }}$ ed. Instituto Agronômico \& Fundação IAC, Campinas, São Paulo, Brasil.

Rao, I.M., D.K. Friesen, and M. Osaki. 1999. Plant adaptation to phosphorus-limited tropical soils. p. 61-95. In Pessarakli, M. (ed.) Handbook of plant and crop stress. $2^{\text {nd }}$ ed. Marcel Dekker, New York, USA.

Sanchez, C.A. 2006. Phosphorus. p. 51-90. In Barker, A.V., and D.J. Pilbeam (eds.) Handbook of plant nutrition. Taylor \& Francis Group, Boca Raton, Florida, USA.

Sharpley, A.N., T. Daniel, T. Sims, J. Lemunyon, R. Stevens, and R. Parry. 2003. Agricultural phosphorus and eutrophication. 38 p. $2^{\text {nd }}$ ed. Agricultural Research Service, Washington D.C., USA. Available at http://www.ars.usda.gov/is/np/Phos\&Eutro2/ agphoseutro2ed.pdf (accessed January 2012).
Trani, P.E., F.A. Passos, J.A. Azevedo, e M. Tavares. 1997. Brócolos, couve-flor e repolho. In Raij, B. van et al. (eds.) Recomendações de adubação e calagem para o Estado de São Paulo. Boletim Técnico 100. p. 175. Instituto Agronômico \& Fundação IAC, Campinas, São Paulo, Brasil.

Trani, P.E., e B. van Raij. 1997. Hortaliças. In Raij, B. van, et al. (eds.) Recomendações de adubação e calagem para o Estado de São Paulo. Boletim Técnico 100. p. 157-164. Instituto Agronômico \& Fundação IAC, Campinas, São Paulo, Brasil.

Soil Survey Staff. 1975. Soil taxonomy: A basic system of soil classification for making and interpreting soil surveys. Handbook 436. 754 p. Natural Resources Conservation Service, U.S. Department of Agriculture, Washington, D.C., USA.

Valladares, G.S., M.G. Pereira, e L.H.C. Anjos. 2003. Adsorção de fósforo em argila de atividade baixa. Bragantia 62:111-118.

Wang, Z., and S. Li. 2004. Effects of nitrogen and phosphorus fertilization on plant growth and nitrate accumulation in vegetables. Journal of Plant Nutrition 27:539-556. 